\title{
The Effect of Information Systems Efficiency On Effectiveness of Decision Making: A Field Study in Algerian Banks
}

\section{Dr. Benabou Djilali}

Professor

\section{Abstract:}

This study aimed at identifying the effect information system efficiency on effectiveness of decision making in Algerian banks. And to achieve the study objectives, A questionnaire was developed and distributed, which consist of (50) subjects, (45) questionnaire of which were returned and analyzed. Validity and reliability of questionnaires were computed. The results of the study refer to significant statistical effect of information system competency on effectiveness of decision making in banks sample study. The study attains the following results:

\section{Relational Relations between Variables:}

- There is significant positive correlation between the efficiency of information systems and the effectiveness of decision-making at the level of significance $(0,01)$.

- There is significant positive correlation between the dimensions of the information systems efficiency (quality of the hardware used, suitable information, the efficiency of workers), and the dimensions of the effectiveness of the decision-making (quality of decision, the time of decision-making, ease of decision-making, taking into account the acceptance of the resolution by the staff) at the level of significance $(0,01)$.

\section{Effect Relationships between Variables:}

- The quality of the hardware used in the information system affect positively and significantly on the effectiveness of the decision-making.

- There is positively and significantly affect of the suitability of the information on the effectiveness of the decision-making.

- The efficiency of workers in the information system affect positively and significantly on the effectiveness of the decision-making.

In the light of the findings; some recommendations are given.

\section{1- Introduction and Research Problem:}

The use of information is the backbone of modern societies, it has become an important part of the time spent by the individual in the performance of his work, The environment surrounding organizations are characterized by constant and rapid change, and to keep pace with this change; any organization must be available to have an information system. the information systems was not interest organizations in the mid-sixties, because of the high cost of computers and its large size on the one hand, and the lack of a specialized applications in the different administrative areas on the other hand, and also because the computers need people specialists to operate and handle them. But In recent times, with the emergence of the global

* This article was submitted in July 2015, and accepted for publishing in September 2015. 
economy, as well as shifts in both industrialized economies and organizations; the importance of information systems have seen a steady and quickly increase. This development in the field of information system has contributed in support of the management decision-making process within the administrative organizations of various qualities and goals, as the decision-making process is of course only deal is based primarily on the quality of information to be utilized in the face of problems or dealing with the development and make the appropriate changes in the Organization. The banking sector like other sectors seeking to take advantage of information systems in the treatment of the vast amount of data that it handles, as well as ensure effective decision-making, success of banks in the decision-making depends on what is available from the appropriate information, and from this perspective can be formulated research problem as follows: What is the impact of the efficiency of information systems on the effectiveness of decision-making in the Algerian banks?

\section{2- Research Objectives:}

This research aims to identify the impact of the efficiency of information systems on the effectiveness of decision-making in the Algerian banks, also aims at the following:

- Determine the nature of the correlations between the efficiency of information systems and the effectiveness of decision-making in the study sample banks.

- Analysis of the impact of the efficiency of information systems (hardware quality, efficient of workers, suitability of the information) on the effectiveness of decision-making in the Algerian banks.

- $\quad$ Provide a set of recommendations and suggestions that could benefit the banks under study in efficiency of decision-making through efficient information systems.

\section{3- The Importance of Research:}

The importance of research could clear in the following points:

- The challenges and the growing pressures that surround the banking sector on each side in each area, increase the importance of the information and its role in the success of this sector and its continuation, as we find that the availability of information at the right time can contribute to the success of the decision-making process.

4- As the importance of research also stems from the application domain, which included the banking sector has been chosen as this sector of great importance in supporting the national economy, it is also the most affected sectors about what the world is witnessing from the openness and development in informations and communications technology and highly competitive.

\section{5- Research Variables:}

Independent Variable: is the efficiency of information systems and this variable will be studied through the following dimensions (the quality of the hardware used, the efficiency of workers in information systems, suitability of the information).

The Dependent Variable: is the effectiveness of decision-making and this variable will be studied through the following dimensions: (quality decision, decision-making time, eases of implementation of the decision, taking into account the acceptance of the decision by the staff). 


\section{6- Procedural Definitions:}

\section{Information System:}

As defined by (O’Brien, 1997: 4) the information system is: "A group of individuals, hardware, software, networks, and data collected resources, transformation, and distribution of information in organizations".

\section{Decision-Making:}

Decision-Making defined as the "conscious and human process, involving both individual and social phenomenon based upon factual and value premises, which concludes with a choice of one behavoural activity from among one or more alternatives with the intention of moving toward some desired state of affairs" (ismail, 2011: 178)

\section{7- Research Hypotheses:}

\section{First: The Correlation Hypotheses:}

a- There is a positive correlation statistically significant between the efficiency of information systems and the effectiveness of decision-making in the Algerian banks.

- There is a positive correlation statistically significant between the quality of the hardware used and the effectiveness of decision-making in the Algerian banks.

- There is a positive correlation statistically significant between the efficiency of workers and the effectiveness of decision-making in the Algerian banks.

- There is a positive correlation statistically significant between the suitability of the information and the effectiveness of decision-making in the Algerian banks.

\section{Second: The Effect Hypotheses:}

b- There is a statistically significant effect of the efficiency of information systems on the effectiveness of decision-making in the Algerian banks.

- There is a statistically significant effect of the quality of the hardware used on the effectiveness of decision-making in the Algerian banks.

- There is a statistically significant effect of the efficiency of workers on the effectiveness of decision-making in the Algerian banks.

- There is a statistically significant effect of the suitability of the information on the effectiveness of decision-making in the Algerian banks.

\section{7- Previous Studies:}

(Sasvari, 2013) Study, The aim of this study was to detect the impacts of using business information systems on operational effectiveness in Hungary, the results clearly showed that according to the majority of the respondents the informations supply for decision makers improved. In contrast, business information systems as a means of improving competitiveness were only regarded by corporations, this aspect was only around the average in other company size categories. Corporations also had the greatest expectations in terms of decreasing the time needed for making decisions, whereas micrornterprises only moderately agreed with these statements.

(Olumoge, 2013) Study, This study uses field survey responses from senior management staff of five different insurance companies to empirically examine the relationship of information systems as used by the management for decision making, speed, availability of information and involvement of subordinates in decision making. The results showed that: 
- Information systems have impacts on management decision making in the insurance sector.

- Information systems prooduce relevent, timely and accurate information for effective decision making.

- Information systems have improved the quality of decision making thereby leading to higher productivity.

(Ismail, 2011) Study, this Study aims at highlighting the significance and importance of utilizing marketing information systems on decision making, by clarifying the need for quick and efficient decision making due to time saving and preventing of duplication of work. The empirical study findings confirmed positive relationships between the level of utilizing and adopting "decision support system and marketing intelligence" and the success of an organizational decision making.

(Hussain \& Others, 2006) Study, entitled the use of human resources information systems on human resource management professionals the study included institutions of all sizes, focusing on those that are becoming increasingly focused on the management information systems for competitive advantages. The results showed that the human resources information systems provide accurate information in a timely manner to users of human resources, as well as senior management in support of the strategic decision-making, regardless of size.

(Beadles \& Others, 2005) Study, entitled (The impact of human resource information systems: an exploratory study in the public sector) this study aimed to gather information on the application of human resources information systems, the future benefits, satisfaction on the system, and finally, Strategic Influence. It was concluded that $80 \%$ of HR managers believe that the human resources information systems have improved their ability to disseminate information and increased the amount of useful information. Moreover, 90\% of HR managers believe that the human resources information produces value-added. And $60 \%$ of them answered that the system provides information useful in making decisions relating to promotions.

In light of the foregoing, agrees this study with previous studies on the importance of technology and information systems in service of the goals and orientations of business organizations, while different current study from previous studies in its focus on the impact of information systems in terms of: (quality of hardware used, suitability of the information, the efficiency of workers) on the effectiveness of decision-making, and also vary in terms of the practical field on the Algerian banks which is experiencing increasing competition, especially in light of the facilities granted to the foreign investor to expand and direct its activities in the banking sector in Algeria.

\section{8- Theoretical Framework:}

\section{Information Systems: Concept and Importance}

Included (Alter, 1990: 43)'s definition of the information system to distinguish between each of the information technology, information system, work system and this is as follows:

\section{Information Technology:}

According to alter, is the hardware and software used by the information system.

\section{Information System:}

Is a special type of work system that uses information technology to collect, transfer, storage, retrieval, management and presentation of information, and this is to support the business system or more? 


\section{Work System:}

Is a system in which participants completion operations Business use of information, technology, and other of resources to produce customer-oriented products.

A Firm: Include an overlapping work system which Work together to roduce products or services to external customers in the business environment.

The Business Environment containing the Firm itself and anything that affects their success, such as: Competitors, suppliers, customers, demographic conditions, social, and economic development.

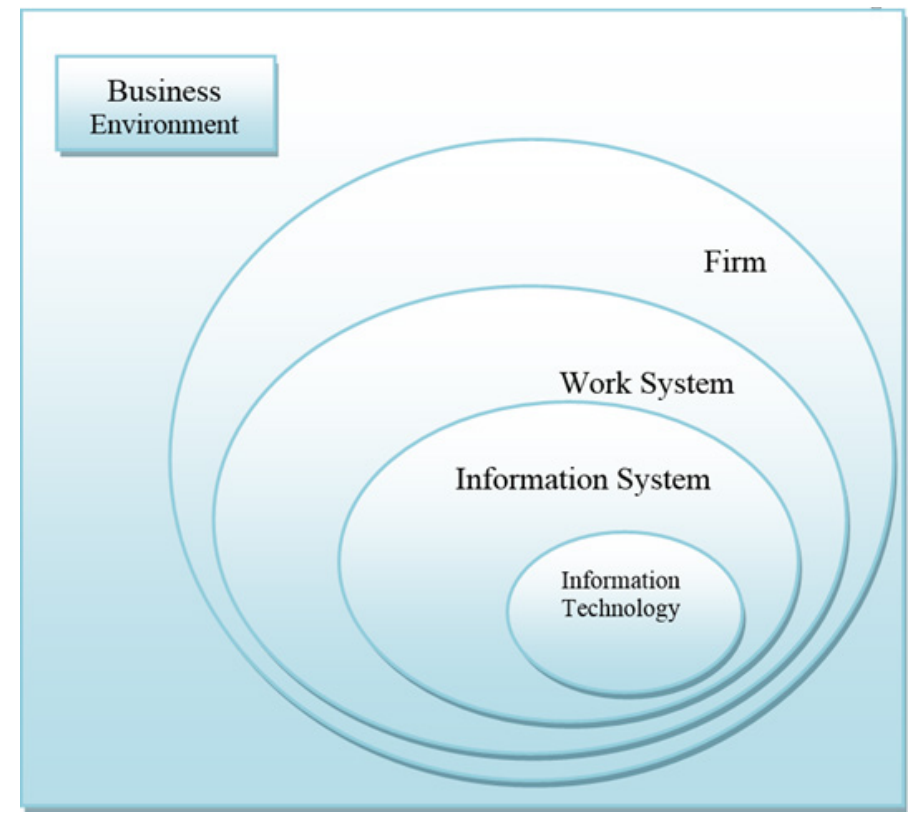

Source: Alter, Steven. Op Cit. p 43

Figure N (1) Information Technology, Information System, Work System

\section{The Fundamental Roles of Information Systems:}

Information systems perform three roles in any type of organization: (O'Brien, 2000: 10)

- $\quad$ Support of business process and operations.

- $\quad$ Support of decision making by its employees and management.

- Support of its strategies for competitive advantage.

\section{The Decision-making Process:}

The decision-making process can be broken down into six steps (lunenburg, 2010: 2-7)

\section{1- Identifying the Problem:}

kepner and tregoe developed a method of problem analysis includes (1) :problem identificatio (2), definition of what the problem is and is not (3), prioritizing the problem ,and(4) testing for cause effect relationships.

\section{2- Generating Alternatives:}

Once the problem has been identified, the second step in the decision making process is to generate alternative to the problem. The extent of search for alternatives is limited by the 
importance of the decision, the cost and value of additional information needed to evaluate alternatives, and the number of people affected by the decision.

\section{3- Evaluating Alternatives:}

In evaluting an alternative, administrators must ask the following three questions: (1) "is the alternative feasible?”Is it a satisfatory alternative? "(3) "what impact will it have on people?”

\section{4- Choosing an Alternative:}

Once the administrator has evaluated all of the alternatives, he attempts to choose the best alternative. The evaluation phase will have eliminated some of the alternatives, but in most cases two or more will remain.

\section{5- Implementing the Decision:}

After choosing an alternative, the administration faces the challenge of implementing the decision. A sound decision can fail if implemented poorly. It is useful, therefore, to consider some suggestions for successful implementation:

- Administrators need to make sure that the alternative is clearly understood.

- Administrators need toencourage acceptance of the alternative as a necessary course of action.

- $\quad$ Administrators need to provide enough resources to make the alternative succeed.

- Administrators need to establish workable timelines.

- Administrators need to assign responsabilities clearly.

\section{6- Evaluating Decision Making:}

When an implemented decision does not produce the desired results, there are probably a number of cause's incorrect deffinition of the problem, poor evaluation of alternatives, and/or improper implementation. Among these possible causes, the most common and serious error is an inadequate definition of the problem. When the problem is incorrectly defined, the alternative that is selected and implemented will not produce the desired result.

\section{Research Methodology:}

\section{1- Research Methodology User:}

The study was descriptive and analytical research methodology, at the level of descriptive research, the desktop survey was conducted in addition to viewing on theoretical and practical studies and researches. As for the analytical field research, a questionnaire has been used for the purpose of detecting the views of managers in each of the middle and upper management on a number of variables and assumptions that are the basis of this research.

\section{2- Society and the Research Sample:}

After identified the study's researcher community in banks subject of study, a random sample of the managers of these banks has taken. The research sample included two administrative levels (senior management, central) of both sexes, and multiple scientific qualifications, and different experiences. The number of questionnaires distributed was (50) director, recalled (45) of them, so the percentage of a recovery is $(90 \%)$. And it is a good percentage. 


\section{3- Search Tool:}

a- Description of Tool: To answer the study questions and the hypotheses, researchers developed a questionnaire depending on a number of studies in the field of information systems and the effectiveness of decision-making, which include the following:

- $\quad$ Part I: singled out this part data and personal information (demographic variables) for the study sample (sex, qualification, the administrative level, and years of experience).

- $\quad$ Part II: This part included (24) paragraph measure the (efficient information systems), from (1-9) measured the quality of the hardware used, the paragraphs (10-16) measured the efficiency of workers in information systems, while measured paragraphs of (16 24) suitability of the information.

- $\quad$ Part III: this part included (12) paragraph by which to measure (the effectiveness of decision-making), (25-27) measured the quality of decision-making, and measured paragraphs (28-30) decision-making time, and paragraphs (31-33) measured ease of decision-making, and measured paragraphs (34-36) take into account the acceptance of the decision.

b- Tool Validity: to ascertain the veracity of the tool, the researchers with the assistance of a number of professors, specialists, make sure how to formulate questions and clarity and how it fits with the subject matter for which it was designed for, and the researchers conducted amendments requested by specialists before the distribution.

c- Tool Reliability: to ascertain the veracity of the tool, the researchers use the reliability Test.

Table (1): Test Reliability (Coefficient of Cronbach's Alpha)

\begin{tabular}{ccccc}
\hline Variable Name & $\begin{array}{c}\text { Information Sys- } \\
\text { tems Efficiency }\end{array}$ & $\begin{array}{c}\text { Effectiveness of } \\
\text { Decision-making }\end{array}$ & $\begin{array}{c}\text { Overall Stability of } \\
\text { The Questionnaire }\end{array}$ \\
\cline { 3 - 4 } $\begin{array}{c}\text { Reliability Coefficient } \\
\text { (Alpha Cronbach) }\end{array}$ & 0,891 & 0,934 \\
0,890 \\
\hline
\end{tabular}

Illustrated by the table; reliability coefficients for all the variables of the study are high and suitable for the purposes of the study, indicate the consolidation of the overall concept of the content of the questionnaire and the concept of each question.

Statistical Treatment: we have been using the following statistical methods: Descriptive Methods: including: (numbers and percentages, arithmetic mean, standard deviation, standard error).

Analytical Methods: including: (regression analysis, correlation coefficient, coefficient of Cronbach's Alpha).

\section{Analysis of Results:}

\section{1- Descriptive Statistics for the Sample Search.}

Table (2) includes the numbers and percentages of respondents according to the personal and functional characteristics of the study sample as follows: 
Table (2): Distribution of the Sample According to the

Personal and Functional Properties of the Sample

\begin{tabular}{|c|c|c|c|c|c|c|c|}
\hline \multicolumn{2}{|c|}{$\begin{array}{l}\text { Personal and Func- } \\
\text { tional Variables }\end{array}$} & \multirow{2}{*}{$\begin{array}{c}\begin{array}{c}\text { Num- } \\
\text { ber }\end{array} \\
26\end{array}$} & \multirow{2}{*}{$\begin{array}{c}\begin{array}{c}\text { Per- } \\
\text { centage }\end{array} \\
57.8\end{array}$} & \multicolumn{2}{|c|}{ Personal and Functional Variables } & \multirow{2}{*}{$\begin{array}{c}\begin{array}{c}\text { Num- } \\
\text { ber }\end{array} \\
25\end{array}$} & \multirow{2}{*}{$\frac{\%}{55.6}$} \\
\hline \multirow{2}{*}{ Type } & Male & & & & Bachelor & & \\
\hline & Female & 19 & 42.2 & & Graduate & 6 & 13,3 \\
\hline \multicolumn{2}{|c|}{ Total } & 45 & 100 & & Total & 45 & 100 \\
\hline \multirow{3}{*}{$\begin{array}{l}\text { Administra- } \\
\text { tive Level }\end{array}$} & High & 4 & 8,9 & \multirow{4}{*}{$\begin{array}{l}\text { Years } \\
\text { of } \\
\text { Experi- } \\
\text { ence }\end{array}$} & Less Than a Year & 5 & 11,1 \\
\hline & \multirow{2}{*}{ Middle } & \multirow{2}{*}{41} & \multirow{2}{*}{91,1} & & From a Year to Less Than 5 & 10 & 22,2 \\
\hline & & & & & From 5 to Less Than 10 & 13 & 28,9 \\
\hline \multicolumn{2}{|c|}{ Total } & 45 & 100 & & From 10 to Less Than 15 & 17 & 37,8 \\
\hline $\begin{array}{c}\text { Scientific } \\
\text { Qualifica- } \\
\text { tion }\end{array}$ & $\begin{array}{l}\text { Sec- } \\
\text { ondary }\end{array}$ & 14 & 31,1 & & Total & 45 & 100 \\
\hline
\end{tabular}

The number of males in the sample (26) while the number of females (19), and thus the ratio of the total number of male respondents $(57.8 \%)$, and the proportion of females $(42.2 \%)$ . this results reflected the convergence ratios of males and females in high and Central management positions, such as the middle-management directors (91.1\%) of the total respondents, most of the respondents are holders of a bachelor's degree $(62.2 \%)$ of the respondents have experience less than 10 years ( $37.8 \%$ ) have experience of (10 to less than 15 years).

\section{2- Hypotheses Test:}

\section{First: Testing Correlation Hypotheses}

To test each hypothesis of correlation hypotheses, Pearson correlation coefficient were used and the correlation matrix was as follows:

Table (3): Correlation Matrix

\begin{tabular}{|c|c|c|c|c|c|}
\hline Variables & $\begin{array}{l}\text { Quality of } \\
\text { Decision }\end{array}$ & $\begin{array}{c}\text { deci- } \\
\text { sion-mak- } \\
\text { ing Time }\end{array}$ & $\begin{array}{l}\text { Ease of Imple- } \\
\text { mentation of the } \\
\text { Decision }\end{array}$ & $\begin{array}{l}\text { Taking Into } \\
\text { Account the } \\
\text { Acceptance of } \\
\text { the Decision by } \\
\text { the Staff }\end{array}$ & $\begin{array}{c}\text { Effectiveness } \\
\text { of the Decision } \\
\text { - making }\end{array}$ \\
\hline $\begin{array}{l}\text { The Quality of } \\
\text { the Hardware }\end{array}$ & ${ }^{* *} 0,426$ & ${ }^{* *} 0,784$ & ${ }^{* *} 0,484$ & ${ }^{* *} 0,568$ & ${ }^{* *} 0,621$ \\
\hline $\begin{array}{c}\text { The Efficiency } \\
\text { of Workers }\end{array}$ & ${ }^{* *} 0,808$ & ${ }^{* *} 0,781$ & ${ }^{* *} 0,629$ & ${ }^{* *} 0,724$ & ${ }^{* *} 0,888$ \\
\hline $\begin{array}{l}\text { Suitability of } \\
\text { the Informa- } \\
\text { tion }\end{array}$ & $* * 0,494$ & $* * 0,608$ & $* * 0,527$ & ${ }^{* *} 0,619$ & $* * 0,631$ \\
\hline $\begin{array}{c}\text { Efficient Infor- } \\
\text { mation Sys- } \\
\text { tems }\end{array}$ & ${ }^{* *} 0,636$ & ${ }^{* *} 0,829$ & $* * 0,607$ & ${ }^{* *} 0,708$ & ${ }^{* *} 0,796$ \\
\hline
\end{tabular}


Seen From the Table Above, the Following:

- The existence of a correlation positive statistically significant between the independent variable ( the efficiency of information systems) and its various dimensions (the quality of the hardware used, the efficiency of workers, suitability of the information), and the dependent variable (the effectiveness of decision-making) in all its dimensions (quality resolution, the time of decision-making, ease of implementation of the decision, taking into account the acceptance of the decision by the staff) at the level of moral $(0,01)$.

- The strongest correlation was the relationship between the efficiency of workers and (decision quality) and the value of correlation coefficient was $(0,808)$ at the level of moral $(0,01)$.

- The lowest correlation was between (the quality of the hardware used) and (quality resolution), which came worth $(0,426)$ at the level of significance $(0,01)$.

And therefore; hypothesis of research can be accepted: (there is positive correlation statistically significant between the efficiency of information systems and the effectiveness of decision-making in the Algerian banks).

\section{Second: testing Influence Hypotheses:}

a- The effect of the independent variable (the quality of the hardware used) on the dependent variable (the effectiveness of decision-making) using simple linear regression method.

The impact of the quality of the hardware used on the effectiveness of decision-making is testing through a simple linear regression coefficient, and outlined steps up as follows:

Table (4) Summary of the Regression Model

\begin{tabular}{c|ccc}
\hline $\begin{array}{c}\text { Correlation Coeffi- } \\
\text { cient }\end{array}$ & $\begin{array}{c}\text { Regression Coeffi- } \\
\text { cient }\end{array}$ & $\begin{array}{c}\text { Regression Coeffi- } \\
\text { cient Adj }\end{array}$ & $\begin{array}{c}\text { Rtandard Error of } \\
\text { Estimate }\end{array}$ \\
\hline 0,621 & 0,385 & 0,371 & 0,381 \\
\hline
\end{tabular}

This can be explained; that the quality of the hardware used interpreted $(38.5 \%)$ of the variation in the effectiveness of decision-making, a medium- explanatory power, which indicates that there is a statistically significant impact to the quality of the hardware used on the effectiveness of the decision-making.

Table (5) Results of Analysis of Variance

\begin{tabular}{|c|c|c|c|c|c|}
\hline Source & $\begin{array}{l}\text { Degree of } \\
\text { Freedom }\end{array}$ & $\begin{array}{l}\text { Sum of } \\
\text { Squares }\end{array}$ & $\begin{array}{c}\text { Mean } \\
\text { Squares }\end{array}$ & $\begin{array}{l}\text { Value of F } \\
\text { Calculated }\end{array}$ & $\begin{array}{c}\text { Level of } F \\
\text { Significance }\end{array}$ \\
\hline Regression & 1 & 3,915 & 3,915 & \multirow{3}{*}{26,964} & \multirow{3}{*}{0,000} \\
\hline Error & 43 & 6,243 & 0,145 & & \\
\hline Total & 44 & 10,158 & & & \\
\hline
\end{tabular}

The level of $\mathrm{F}$ significance, $(\mathrm{P}-$ Value $=0,000<0,05)$ so the regression model is significant.

Table (6) The Results of Simple Linear Regression Analysis

\begin{tabular}{cccccc}
\hline Variables & B & $\begin{array}{c}\text { Standard } \\
\text { Error }\end{array}$ & Beta & $\begin{array}{c}\text { Value of T } \\
\text { Calculated }\end{array}$ & Level of Significance T \\
\hline Fixed & 1,461 & 0,477 & & 3,060 & 0,004 \\
\hline $\begin{array}{c}\text { The quality of the } \\
\text { hardware used }\end{array}$ & 0,612 & 0,118 & 0,621 & 5,193 & $\mathbf{0 , 0 0 0}$ \\
\hline
\end{tabular}


Evidenced by the statistical results presented in Table (6), and follow-up coefficient (Beta), and test $(\mathrm{T})$ that the quality of the hardware used have a significant effect on the effectiveness of decision-making, as the value of coefficient (Beta) is $(0,621)$, and it is statistically significant at the level of significance (5\%).

And therefore; effect hypothesis was accepted, which provides a significant effect of the quality of the hardware used on the effectiveness of decision - making in the Algerian banks.

b- Effect of suitability of the information on the effectiveness of the decision-making method using simple linear regression.

Effect of suitability of the information on the effectiveness of decision-making was measured through simple linear regression coefficient, and described steps as follows:

Table (7) Summary of the Regression Model

\begin{tabular}{c|ccc}
\hline $\begin{array}{c}\text { Correlation Coeffi- } \\
\text { cient }\end{array}$ & $\begin{array}{c}\text { Regression Coeffi- } \\
\text { cient }\end{array}$ & $\begin{array}{c}\text { Regression Coeffi- } \\
\text { cient Adj }\end{array}$ & $\begin{array}{c}\text { Standard Error } \\
\text { of Estimate }\end{array}$ \\
\hline 0,631 & 0,398 & 0,384 & 0,377 \\
\hline
\end{tabular}

This can be explained; suitability of the information in this form explains what amount $(39.8 \%)$ of the variation in the values of the effectiveness of decision-making which is a medium effect.

Table (8) Results of Analysis of Variance of Variance

\begin{tabular}{|c|c|c|c|c|c|}
\hline Source & $\begin{array}{l}\text { Degree of } \\
\text { Freedom }\end{array}$ & $\begin{array}{c}\text { Sum of } \\
\text { Squares }\end{array}$ & $\begin{array}{c}\text { Mean } \\
\text { Squares }\end{array}$ & $\begin{array}{l}\text { Value of } \mathrm{F} \\
\text { Calculated }\end{array}$ & $\begin{array}{l}\text { Level of Signif- } \\
\text { icance F }\end{array}$ \\
\hline Regression & $T$ & 4,041 & 4,041 & \multirow{3}{*}{28,399} & \multirow{3}{*}{0,000} \\
\hline Error & 43 & 6,118 & 0,142 & & \\
\hline Total & 44 & 10,158 & & & \\
\hline
\end{tabular}

The level of $\mathrm{F}$ significance, $(\mathrm{P}-$ Value $=0,000<0,05)$ so the regression model is significant.

Table (9) The Results of Simple Linear Regression Analysis

\begin{tabular}{cccccc}
\hline Variables & B & $\begin{array}{c}\text { Standard } \\
\text { Error }\end{array}$ & Beta & $\begin{array}{c}\text { Value of T } \\
\text { Calculated }\end{array}$ & $\begin{array}{c}\text { Level of Signifi- } \\
\text { cance T }\end{array}$ \\
\hline Fixed & 0,240 & 0,693 & & 0,346 & 0,731 \\
\hline $\begin{array}{c}\text { Suitability of the In- } \\
\text { formation }\end{array}$ & 0,947 & 0,178 & 0,631 & 5,329 & $\mathbf{0 , 0 0 0}$ \\
\hline
\end{tabular}

Evidenced by the statistical results presented in Table (9), and follow-up coefficient (Beta), and test $(\mathrm{T})$ that the suitability of the information have a significant effect on the effectiveness of decision-making, as the value of coefficient (Beta) is $(0,631)$, and it is statistically significant at the level of significance (5\%).

And therefore; effect hypothesis was accepted, which provides a significant effect for the suitability of information on the effectiveness of decision-making in the Algerian banks.

c- Effect of efficiency of workers on the effectiveness of the decision-making method using simple linear regression.

Effect of efficiency of workers on the effectiveness of decision-making was measured through simple linear regression coefficient, and described steps as follows: 
Table (10) Summary of the Regression Model

\begin{tabular}{cccc}
\hline $\begin{array}{c}\text { Correlation Coeffi- } \\
\text { cient }\end{array}$ & $\begin{array}{c}\text { Regression coeffi- } \\
\text { cient }\end{array}$ & $\begin{array}{c}\text { Regression Coeffi- } \\
\text { cient Adj }\end{array}$ & $\begin{array}{c}\text { Standard Error of } \\
\text { Estimate }\end{array}$ \\
\hline 0,888 & 0,788 & 0,783 & 0,223 \\
\hline
\end{tabular}

This can be explained; (78.8 \%) of the total deviations in the values of the effectiveness of the decision-making interpret the efficiency of workers in information systems which is a high explanatory power.

Table (11) Results of Analysis of Analysis of Variance

\begin{tabular}{|c|c|c|c|c|c|}
\hline Source & $\begin{array}{l}\text { Degree of } \\
\text { Freedom }\end{array}$ & $\begin{array}{l}\text { Sum of } \\
\text { Squares }\end{array}$ & $\begin{array}{c}\text { Mean } \\
\text { Squares }\end{array}$ & $\begin{array}{l}\text { Value of } F \\
\text { Calculated }\end{array}$ & $\begin{array}{l}\text { Level of Sig- } \\
\text { nificance } F\end{array}$ \\
\hline Regression & 1 & 8,008 & 8,008 & \multirow{3}{*}{160,142} & \multirow{3}{*}{0,000} \\
\hline Error & 43 & 2,150 & 0,050 & & \\
\hline Total & 44 & 10,158 & & & \\
\hline
\end{tabular}

The level of $\mathrm{F}$ significance, $(\mathrm{P}-$ Value $=0,000<0,05)$ so the regression model is significant.

Evidenced by the statistical results in the table (12), and follow-up coefficient (Beta), and test (T) that the efficiency of workers have an impact on the effectiveness of decision-making, as the value of coefficient (Beta) is $(0,888)$, and it is statistically significant at the significance level $(5 \%)$.

Table (12) The Results of Simple Linear Regression Analysis

\begin{tabular}{cccccc}
\hline Variables & B & $\begin{array}{c}\text { Standard } \\
\text { Error }\end{array}$ & Beta & $\begin{array}{c}\text { Value of T } \\
\text { Calculated }\end{array}$ & $\begin{array}{c}\text { Level of Sig- } \\
\text { nificance T }\end{array}$ \\
\hline Fixed & 0,493 & 0,273 & & 1,804 & 0,078 \\
\hline $\begin{array}{c}\text { The Efficien- } \\
\text { cy of Workers }\end{array}$ & 0,759 & 0,060 & 0,888 & 12,655 & $\mathbf{0 , 0 0 0}$ \\
\hline
\end{tabular}

And therefore; effect hypothesis was accepted, which provides a significant effect to the efficiency of workers in the information system on the effectiveness of decision - making in the Algerian banks.

Through the above hypothesis we can accept the major research hypothesis provides a significant effect to the efficiency of information systems on the effectiveness of decision making in the Algerian banks.

\section{Search results:}

Based on the above analysis, the following conclusions can be installed:

Results showed an improvement in the proportion of women working to central and high management positions, and this is reflected in the ratio of males and females in the sample. The results also showed that the managers of the high and central management constitute a class educated to accept and accommodate the idea of introducing information systems and reliable addition to accommodate them the possibility to take advantage of these systems to ensure effectiveness in making various decisions banking, as well as trying to keep up with recent developments especially in light of intense competition. The results showed that high and central management managers in the banks under study with a good experience in the banking sector which is facilitates the use of information systems used in decision-making. 


\section{Relational relations between the variables:}

1- There is significant positive correlation between the efficiency of information systems and the effectiveness of decision-making at the level of significance $(0,01)$.

2- There is significant positive correlation between the dimensions of the efficiency of information systems (quality of the hardware used, suitable information, the efficiency of workers), and the dimensions of the effectiveness of the decision-making (quality of decision, the time of decision-making, ease of decision-making, taking into account the acceptance of the resolution by the staff) at the level of significance $(0,01)$.

3- the strongest correlations were among the efficiency of workers and (quality resolution), and the lowest was among (the quality of the hardware used) and (quality resolution) at the level of moral $(0,01)$.

And therefore; hypothesis of the research related to the existence of a significant correlation between the efficiency of information systems and the effectiveness of decision-making in the Algerian banks was accepted.

\section{Effect relationships between variables:}

1- The quality of the hardware used in the information system affect positively and significantly on the effectiveness of the decision-making.

2- There is positively and significantly affect of the suitability of the information on the effectiveness of the decision-making.

3- The efficiency of workers in the information system affect positively and significantly on the effectiveness of the decision-making.

And therefore; hypothesis of the research related to the existence of a significant effect to the efficiency of information systems on the effectiveness of decision - making in the Algerian banks was accepted.

\section{Recommendations and Future Research:}

Depending on the results presented, we can propose the following recommendations:

Maximizing the use of information system in decision-making because there is a strong correlation and impact among the efficiency of the information system and effectiveness of decision making.

Continuous updating of operating systems in banks under study between the duration and the other, to make sure they do not impede the work of information systems, and to avoid any expectations can occur unexpectedly.

The formation of a working group to follow up and organize existing regulations, according to a sound scientific basis, that this team includes managers from among its members specialists from all departments, and based on this system in the bank, as well as technicians in the design and implementation of such systems.

Training of information systems and beneficiaries of the operating systems in general, by sending them in specialized courses operating systems, and subjected to tests on systems that trained them, to be sure of the feasibility of training on those systems, and should not be limited 
to the training process of these on how to use systems only, but must also include recognition capabilities of the hardware and software used.

Increase support for the senior management of information system users and those who support it through:

- To encourage them to use the information system and understand their different needs, and to explore their views about the problems they face when using the system until it is overcome.

Recommendations of the Researchers with Regard to Future Research and Studies:

- It important for future studies, taking into account other dimensions of the study variables to expand understanding about the impact of Information Systems efficiency on effectiveness of decision making.

- Make the same study with the same variable on sample of Algerian corporations, and the multinational corporations. 


\section{References}

- $\quad$ Alter, Steven.1999) ). Information Systems Management Perspective. $3^{\text {rd }}$ Ed. Wesley Educational Publishers, Ins.

- Beadles, Nicholas Aston \& Others. (2005). "The Impact of Human Resource Information Systems: An Exploratory Study In the Public Sector", Communication of the IIMA, Vol. 5, Issue 4.

- Hussain \& Others. (2007). "The Use of Human Resource Information Systems on Human Resource Management Professionals", Information and Management, Vol. 44, issue 1, p. 74 - 89, Available Online at: www. Sciencedirect. Com.

- Ismail, Shaker Turki. (2011). "The Role of Marketing Information System on Decision Making "An Applied Study on Royal Jordanian Air Lines (RJA)", International Journal of Business and Social Science, Vol. 2, No. 3, Special Issue.

- $\quad$ Lunenburg, Fred C. (2010). "The Decision Making Process", National Forum of Educational Administration and Supervision Journal, Vol. 27, No. 4.

- O'Brien, James. (1997). Introduction to Information System. $9^{\text {th }}$ Ed. Irwin: The McGraw-Hill Companies, Inc,

- O'Brien, James. (2000). Introduction to Information Systems Essentials for the Internetworked Enterprise. $9^{\text {th }}$ Ed. The McGraw-Hill Companies Inc., USA.

- Olumoge, Mosud Y. (2013). "Impact of Information Systems on Management Decision Marketing in the Nigerian Insurance Sector", International Journal of Scientific \& Technology Research. Vol. 2, Issue 12, December.

- Sasvari, Peter. (2013). The Impacts of Using Business Information Systems on Operational Effectiveness in Hangary, International Journal of Emerging Research in Management \& Technology, Vol. 2, issue4. 